\title{
Effect of Nutrients Management Modules for Minimizing Drought Impact and Groundnut Yield Maximization in Rainfed Conditions
}

\author{
V.D. Vora*, D.S. Hirpara, P.D. Vekaria, K. Jotangiya, S.C. Kaneria \\ N.R. Desai and V.L. Modhavadiya \\ Dry Farming Research Station, Junagadh Agricultural University, \\ Targhadia (Gujarat)-360 003, India \\ *Corresponding author
}

\section{A B S T R A C T}

\section{Keywords}

Groundnut,

Nutrients,

Management,

Modules, Yield,

Water use

efficiency

\section{Article Info}

Accepted:

07 October 2019

Available Online:

10 November 2019
A field experiment was conducted at Dry Farming Research Station, Junagadh Agricultural University, Targhadia (Gujarat) during kharif seasons of 2013 to 2016 to ascertain the effect of nutrients management modules for minimizing drought impact and groundnut yield maximization in rainfed conditions. The experiment was laid out in randomized block design with ten different treatments viz., $\mathrm{T}_{1}$-Absolute control, $\mathrm{T}_{2}$-Water spray-no nutrients, $\mathrm{T}_{3}$-Foliar spray of water soluble fertilizer @ $1 \%$ (NPK-19-19-19) at 30 to 35 DAS, T -Foliar spray of Fe \&

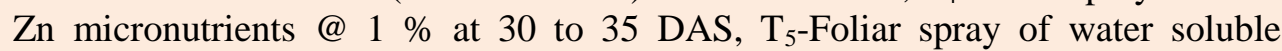
fertilizer@1\% (NPK-19-19-19) and Fe \& Zn micronutrients @ $1 \%$ at 30 to 35 DAS, $\mathrm{T}_{6}$-Foliar spray of selenium @ $20 \mathrm{~g} /$ ha at 30 to $35 \mathrm{DAS} \mathrm{T}_{7}$-Foliar spray of 2 $\%$ Urea at 30 to 35 DAS T -Foliar spray of $\mathrm{KNO}_{3} 2 \%$ at 30 to 35 DAS T 9 Foliar spray of $\mathrm{KNO}_{3} 2 \%$ at 60 DAS T 10 Foliar spray of $2 \%$ Urea at 30 to 35 DAS + $\mathrm{KNO}_{3} 2 \%$ at 60 DAS were evaluated in randomized block design with three replications. The farmers of North Saurashtra Agro-climatic Zone growing groundnut GG-20 are advised to make foliar spray of $2 \%$ urea at 30 to 35 DAS for obtaining higher productivity and maximum net returns and improving water use efficiency under dry farming conditions.

\section{Introduction}

Groundnut is one of the most popular and universal crop cultivated in more than 120 countries. In India, it is cultivated on area of $5.53 \mathrm{M}$ ha with production of $9.67 \mathrm{M}$ tones and productivity of $1750 \mathrm{~kg} \mathrm{ha}^{-1}$ during 2013-
2014 (AICRPG, 2015). Based on rainfall pattern, soil factors, diseases and pest situations, groundnut growing area in India has been divided into five zones. Currently six states viz., Gujarat, Andhra Pradesh, Karnataka, Tamil Nadu, Maharashtra and Rajasthan account for more than $90 \%$ of the 
total groundnut area and $89.3 \%$ of total groundnut production. Madhya Pradesh, Uttar Pradesh, Odisha and West Bengal are the other states having substantial area under this crop. Among the major groundnut growing states, Gujarat rank first in area (1.84 M ha) and production (4.92 $\mathrm{M}$ tones) with productivity of $2670 \mathrm{~kg} \mathrm{ha}^{-1}$ (AICRPG, 2015). Nutrient management module plays an important role in boosting groundnut production. Among the various agronomic practices, nutrient management has an important role in maximizing the pod yield. Nutrients affected all most growth and yield attributing characters and yields through its doses as well as sources. Groundnut is an important oilseed crop of dry farming region in the tropics and subtropics.

The groundnut crop suffers from moisture and nutrients stress during dry spells and need to supplement during this period. The balanced supply of nutrients enables the crop to cope up dry spells. Hence, the trial is formulated to test the effect of different chemical on crop yield. Considering the facts and views highlighted above, the present study was undertaken to assess the Effect of nutrients management modules for minimizing drought impact and groundnut yield maximization in rain fed regions.

\section{Materials and Methods}

A field experiment entitled "Effect of nutrients management modules for minimizing drought impact and groundnut yield maximization in rain fed regions.' was carried out at Dry Farming Research Station, Junagadh Agricultural University, Targhadia (Gujarat) during kharif seasons of 2013 to 2016.

The experiment comprising ten treatments of nutrient management viz., $\mathrm{T}_{1}$-Absolute control, $\mathrm{T}_{2}$-Water spray-no nutrients, $\mathrm{T}_{3}$-Foliar spray of water soluble fertilizer @ $1 \%$ (NPK-
19-19-19) at 30 to $35 \mathrm{DAS}, \mathrm{T}_{4}$-Foliar spray of Fe and Zn micronutrients @ 1\% at 30 to 35 DAS, T 5 -Foliar spray of water soluble fertilizer @ $1 \%$ (NPK-19-19-19) and Fe \& Zn micronutrients@1\% at 30 to $35 \mathrm{DAS}, \mathrm{T}_{6}$ Foliar spray of selenium @ $20 \mathrm{~g} / \mathrm{ha}$ at 30 to 35 DAS $\mathrm{T}_{7}$-Foliar spray of $2 \%$ Urea at 30 to 35 DAS $\mathrm{T}_{8}$-Foliar spray of $\mathrm{KNO}_{3} 2 \%$ at 30 to 35 DAS $\mathrm{T}_{9}$ Foliar spray of $\mathrm{KNO}_{3} 2 \%$ at 60 DAS and $\mathrm{T}_{10}$ Foliar spray of $2 \%$ Urea at 30 to 35 DAS $+\mathrm{KNO}_{3} 2 \%$ at 60 DAS were evaluated in randomized block design with three replications.

The soil of the experimental plot was medium black, $\mathrm{pH} 8.0$ and organic carbon $0.67 \%$. The soil was low in available phosphorus (10.20 $\left.\mathrm{kg} \mathrm{ha}^{-1}\right)$, potash $\left(327 \mathrm{~kg} \mathrm{ha}^{-1}\right)$ and medium in zinc and iron. Groundnut cv. GG 20 was sown at $60 \mathrm{~cm}$ spacing with $100 \mathrm{~kg}$ seed ha ${ }^{-1}$ in first week of July.

The recommended dose of fertilizers @ 12.5:25.0:00 kg NPK/ha. Other cultural operations were done as per recommendation and crop requirements. Regularly biometric observations were recorded at specific time intervals by selecting randomly five plants in each treatment. Finally the crop was harvested and produce were dried, threshed, cleaned and weighed.

\section{Results and Discussion}

\section{Growth parameters}

The pooled result given in table 1 revealed that effect of nutrient management treatments on plant height, number of branches, number of pods as well as number of nodules per plant were remain non-significant.

These findings are in close conformity with those reported by Salve et al., (2010), Deshmukh et al., (2012), Patil et al., (2014), Bhosale and Pisal (2017). 


\section{Yield}

\section{Pod yield of groundnut}

The result given in table 2 indicated that effect of nutrient management on pod yield of groundnut were found significant during year 2014-15, 2015-16 and 2016-17 and nonsignificant 2013-14 and in pooled results. The data also revealed that higher pod yield (1655 $\mathrm{kg} / \mathrm{ha}$ ) was recorded under $\mathrm{T}_{7}$ (Foliar spray of $2 \%$ urea at 30 to $35 \mathrm{DAS}$ ) in pooled results of four successive years. Whereas, lower pod yield $(1206 \mathrm{~kg} / \mathrm{ha})$ was recorded under $\mathrm{T}_{1}$ (absolute control). The findings are close with findings of Thorave and Dhonde (2008), Sharmaet al., (2011), Deshmukh et al., (2012), Bhosale and Pisal (2017).

Table.1 Biometric observation as affected by different treatments (Mean)

\begin{tabular}{|c|c|c|c|c|c|}
\hline $\begin{array}{l}\text { Tr. } \\
\text { No. }\end{array}$ & Treatments & $\begin{array}{l}\text { Plant } \\
\text { height } \\
(\mathbf{c m})\end{array}$ & $\begin{array}{c}\text { No. of } \\
\text { branches/pl. }\end{array}$ & $\begin{array}{l}\text { No of } \\
\text { pod/ } \\
\text { plant }\end{array}$ & $\begin{array}{l}\text { No of } \\
\text { nodules/ } \\
\text { plant }\end{array}$ \\
\hline $\mathbf{T}_{1}$ & Absolute control & 28 & 6 & 8 & 21 \\
\hline $\mathbf{T}_{2}$ & Water spray-no nutrients & 26 & 6 & 8 & 20 \\
\hline $\mathbf{T}_{\mathbf{3}}$ & $\begin{array}{l}\text { FS of water soluble fertilizer @ } 1 \% \\
\text { (NPK-19-19-19) at } 30 \text { to } 35 \text { DAS }\end{array}$ & 27 & 6 & 8 & 18 \\
\hline $\mathbf{T}_{4}$ & $\begin{array}{c}\text { Foliar spray of Fe \& } \mathrm{Zn} \\
\text { micronutrients @ } 1 \% \text { at } 30 \text { to } 35 \\
\text { DAS }\end{array}$ & 28 & 6 & 8 & 18 \\
\hline $\mathbf{T}_{5}$ & $\begin{array}{l}\text { Foliar spray of water soluble } \\
\text { fertilizer NPK-19-19-19 @ } 1 \% \text { and } \\
\text { Fe \& Zn micronutrients @ } 1 \% \text { at } \\
30 \text { to 35 DAS }\end{array}$ & 27 & 6 & 8 & 21 \\
\hline $\mathbf{T}_{6}$ & $\begin{array}{c}\text { FS of selenium @ } 20 \mathrm{~g} / \mathrm{ha} \text { at } 30 \text { to } \\
35 \mathrm{DAS}\end{array}$ & 27 & 6 & 8 & 19 \\
\hline $\mathbf{T}_{7}$ & $\begin{array}{c}\text { Foliar spray of Urea @ } 2 \% \text { at } 30 \text { to } \\
\text { 35 DAS }\end{array}$ & 29 & 6 & 11 & 22 \\
\hline $\mathbf{T}_{8}$ & $\begin{array}{c}\text { Foliar spray of } \mathrm{KNO}_{3} @ 2 \% \text { at } 30 \\
\text { to } 35 \mathrm{DAS}\end{array}$ & 28 & 6 & 9 & 21 \\
\hline $\mathbf{T}_{9}$ & $\begin{array}{c}\text { Foliar spray of } \mathrm{KNO}_{3} @ 2 \% \text { at } \\
60 \mathrm{DAS}\end{array}$ & 28 & 5 & 8 & 22 \\
\hline $\mathbf{T}_{10}$ & $\begin{array}{c}\text { FS of Urea @ } 2 \% \text { at } 30-35 \text { DAS + } \\
\mathrm{KNO}_{3} @ 2 \% \text { at } 60 \mathrm{DAS}\end{array}$ & 29 & 6 & 8 & 18 \\
\hline & S. Em. \pm & 0.66 & 0.22 & 0.78 & 1.48 \\
\hline & C.D. at $5 \%$ & NS & NS & NS & NS \\
\hline & C.V. \% & 8.3 & 12.9 & 20.1 & 19.9 \\
\hline
\end{tabular}


Table.2 Pod yield of groundnut $(\mathrm{kg} / \mathrm{ha})$ as affected by different treatments

\begin{tabular}{|c|c|c|c|c|c|}
\hline $\begin{array}{l}\text { Tr. } \\
\text { No. }\end{array}$ & Treatments & 2013-14 & 2015-16 & 2016-17 & POOLED \\
\hline $\mathrm{T}_{1}$ & Absolute control & 1222 & 1285 & 1111 & 1206 \\
\hline $\mathrm{T}_{2}$ & Water spray-no nutrients & 1302 & 1337 & 1327 & 1322 \\
\hline $\mathrm{T}_{3}$ & $\begin{array}{l}\text { Foliar spray of water soluble fertilizer @ } 1 \%(\mathrm{NPK}-19-19-19) \text { at } 30 \text { to } 35 \\
\text { DAS }\end{array}$ & 1417 & 1424 & 1389 & 1410 \\
\hline $\mathrm{T}_{4}$ & Foliar spray of Fe \& Zn micronutrients @ $1 \%$ at 30 to 35 DAS & 1444 & 1444 & 1235 & 1374 \\
\hline $\mathrm{T}_{5}$ & $\begin{array}{l}\text { Foliar spray of water soluble fertilizer @ } 1 \%(\mathrm{NPK}-19-19-19) \text { and Fe \& } \\
\qquad \mathrm{Zn} \text { micronutrients @ } 1 \% \text { at } 30 \text { to } 35 \text { DAS }\end{array}$ & 1528 & 1438 & 1420 & 1462 \\
\hline $\mathrm{T}_{6}$ & FS of selenium @ $20 \mathrm{~g} / \mathrm{ha}$ at 30 to $35 \mathrm{DAS}$ & 1472 & 1510 & 1204 & 1395 \\
\hline $\mathrm{T}_{7}$ & Foliar spray of $2 \%$ Urea at 30 to 35 DAS & 1556 & 1528 & 1883 & 1655 \\
\hline $\mathrm{T}_{8}$ & Foliar spray of $\mathrm{KNO}_{3} 2 \%$ at 30 to 35 DAS & 1361 & 1563 & 1481 & 1468 \\
\hline $\mathrm{T}_{9}$ & Foliar spray of $\mathrm{KNO}_{3} 2 \%$ at $60 \mathrm{DAS}$ & 1611 & 1493 & 1821 & 1642 \\
\hline \multirow[t]{4}{*}{$\mathrm{T}_{10}$} & Foliar spray of $2 \%$ Urea at 30 to $35 \mathrm{DAS}+\mathrm{KNO}_{3} 2 \%$ at $60 \mathrm{DAS}$ & 1556 & 1667 & 1605 & 1609 \\
\hline & S. Em. \pm & 119.0 & 68.2 & 255.3 & 96.62 \\
\hline & C.D. at $5 \%$ & NS & 202.7 & NS & 274.11 \\
\hline & C.V. \% & 14.2 & 8.1 & 30.6 & 19.93 \\
\hline
\end{tabular}


Table.3 Haulm yield $(\mathrm{kg} / \mathrm{ha})$ of groundnut as affected by different treatments

\begin{tabular}{|c|c|c|c|c|c|}
\hline $\begin{array}{l}\text { Tr. } \\
\text { No. }\end{array}$ & Treatments & 2013-14 & 2015-16 & 2016-17 & POOLED \\
\hline $\mathrm{T}_{1}$ & Absolute control & 3833 & 3622 & 4917 & 3725 \\
\hline $\mathrm{T}_{2}$ & Water spray-no nutrients & 3861 & 3656 & 4917 & 3640 \\
\hline $\mathrm{T}_{3}$ & $\begin{array}{l}\text { Foliar spray of water soluble fertilizer @ } 1 \%(\mathrm{NPK}-19-19-19) \text { at } \\
\qquad 30 \text { to } 35 \text { DAS }\end{array}$ & 4111 & 4022 & 4417 & 3754 \\
\hline $\mathrm{T}_{4}$ & Foliar spray of Fe \& Zn micronutrients @ $1 \%$ at 30 to 35 DAS & 3458 & 4244 & 4028 & 3601 \\
\hline $\mathrm{T}_{5}$ & $\begin{array}{l}\text { Foliar spray of water soluble fertilizer @ } 1 \%(\mathrm{NPK}-19-19-19) \\
\quad \text { and Fe \& Zn micronutrients @ } 1 \% \text { at } 30 \text { to } 35 \text { DAS }\end{array}$ & 3653 & 3800 & 4806 & 3638 \\
\hline $\mathrm{T}_{6}$ & FS of selenium @ $20 \mathrm{~g} / \mathrm{ha}$ at 30 to $35 \mathrm{DAS}$ & 4153 & 3911 & 4861 & 2499 \\
\hline $\mathrm{T}_{7}$ & Foliar spray of $2 \%$ Urea at 30 to 35 DAS & 4569 & 4000 & 5833 & 4180 \\
\hline $\mathrm{T}_{8}$ & Foliar spray of $\mathrm{KNO}_{3} 2 \%$ at $30-35$ DAS & 3778 & 4089 & 5528 & 3901 \\
\hline $\mathrm{T}_{9}$ & Foliar spray of $\mathrm{KNO}_{3} 2 \%$ at $60 \mathrm{DAS}$ & 4056 & 4200 & 4861 & 3890 \\
\hline \multirow[t]{4}{*}{$\mathrm{T}_{10}$} & $\begin{array}{l}\text { Foliar spray of } 2 \% \text { Urea at } 30 \text { to } 35 \mathrm{DAS}+\mathrm{KNO}_{3} 2 \% \text { at } 60 \\
\text { DAS }\end{array}$ & 4306 & 4506 & 4222 & 3891 \\
\hline & S. Em. \pm & 162.1 & 168.2 & 376.7 & 184.19 \\
\hline & C.D. at $5 \%$ & 481.6 & 499.7 & NS & NS \\
\hline & C.V. \% & 7.1 & 7.3 & 13.5 & 10.67 \\
\hline
\end{tabular}


Table.4 Economics of different treatments

\begin{tabular}{|c|c|c|c|c|c|c|c|}
\hline \multirow{2}{*}{$\begin{array}{l}\text { Tr. } \\
\text { No. }\end{array}$} & \multicolumn{2}{|c|}{ Yield (kg/ha) } & \multirow{2}{*}{$\begin{array}{c}\text { Cost of } \\
\text { cultivation } \\
\text { (Rs/ha) }\end{array}$} & \multirow{2}{*}{$\begin{array}{c}\text { Gross } \\
\text { return } \\
\text { (Rs./ha) }\end{array}$} & \multirow{2}{*}{$\begin{array}{c}\text { Net return } \\
\text { (Rs/ha) }\end{array}$} & \multirow{2}{*}{$\begin{array}{l}\text { B:C } \\
\text { ratio }\end{array}$} & \multirow{2}{*}{$\begin{array}{c}\text { RWUE } \\
\text { (kg/ha- } \\
\text { mm) }\end{array}$} \\
\hline & Pod & Haulm & & & & & \\
\hline $\mathrm{T}_{1}$ & 1206 & 3725 & 25723 & 72895 & 47172 & 1.83 & 2.12 \\
\hline $\mathrm{T}_{2}$ & 1322 & 3640 & 25923 & 77690 & 51767 & 2.00 & 2.32 \\
\hline $\mathrm{T}_{3}$ & 1410 & 3754 & 26673 & 82220 & 55547 & 2.08 & 2.48 \\
\hline $\mathrm{T}_{4}$ & 1374 & 3601 & 26223 & 79835 & 53612 & 2.04 & 2.41 \\
\hline $\mathrm{T}_{5}$ & 1462 & 3638 & 26973 & 83980 & 57007 & 2.11 & 2.57 \\
\hline $\mathrm{T}_{6}$ & 1395 & 2499 & 26723 & 75270 & 48547 & 1.82 & 2.45 \\
\hline $\mathrm{T}_{7}$ & 1655 & 4180 & 25986 & 95375 & 69389 & 2.67 & 2.91 \\
\hline $\mathrm{T}_{8}$ & 1468 & 3901 & 27723 & 85565 & 57842 & 2.09 & 2.58 \\
\hline $\mathrm{T}_{9}$ & 1642 & 3890 & 27723 & 93340 & 65617 & 2.37 & 2.89 \\
\hline $\mathrm{T}_{10}$ & 1609 & 3891 & 28223 & 91860 & 63637 & 2.25 & 2.83 \\
\hline
\end{tabular}

\section{Haulm yield of groundnut}

The result given in table 3 revealed that effect of nutrient management on haulm yield of groundnut were found significant during year 2013-14, 2015-16, 2016-17 and were remained non-significant in year 2014-15and in pooled results. The data also revealed that highest haulm yield (4180 $\mathrm{kg} / \mathrm{ha})$ was recorded under $\mathrm{T}_{7}$ (Foliar spray of $2 \%$ urea at 30 to 35 DAS) and the lowest haulm yield (3601 kg/ha) was recorded under $\mathrm{T}_{4}$ (Foliar spray of Fe and Zn Micronutrients @ $1 \%$ at 30-35 DAS) in pooled results of four successive years. These findings agreement with the results obtained by Thorave and Dhonde (2008), Sharma et al., (2011), Deshmukh et al., (2012), Bhosale and Pisal (2017).

\section{Economics}

Economics response of nutrient management treatments on groundnut crop were worked out on the basis of pooled results which presented in Table 4. The data indicated that Treatment $\mathrm{T}_{7}$ (Foliar spray of $2 \%$ Urea at 30 to 35 DAS) gives highest gross returns (Rs.95375 Rs/ha) and net monitory return (Rs.69389 Rs/ha) with B: C ratio of 2.91. Sharma et al., (2013) and
Vaghasia and Bhalu (2016). Based on field experimentation, it can be concluded that the farmers of North Saurashtra Agro-climatic Zone growing groundnut GG-20 are advised to make foliar spray of $2 \%$ urea at 30 to 35 DAS for obtaining higher productivity and maximum net returns and improving water use efficiency under dry farming conditions.

\section{References}

Anonymous. 2015. Annual Report (kharif 2014) of All India Coordinated Research Project on Groundnut. ICAR- Directorate of Groundnut Research, Junagadh.

Bhosale, N. A. and Pisal, A. A. 2017. Effect of nutrient management on productivity of summer groundnut (Arachis hypogaea L.). Advanced Agricultural Research \& Technology Journal, 1(1): 88-91.

Deshmukh, S.B., Raundal, P.U. and Kunjir, N.T. 2012. Response of groundnut to irrigation and nitrogen fertilizer. Bionfolet, 9(3): 403-407.

Patil, S. R., Kadam, S. R., Kalegore, N.K. and Dadgale, P. R. 2014. Effect of inorganic and bio-fertilizers on growth and yield of summer groundnut. 
Advance Research Journal of Crop Improvement, 5(1): 23-25.

Salve, Y. V., Jadhav, A.S. and Lambade, B.M. 2010. Response of summer groundnut to varying levels of phosphorus and potassium. J. Maharashtra Agril. Unis. 35(2): 178-183.

Sharma, S., Jat, N. L., Shivran, A. C., Choudhry, S., Puniya, M.M and Jeetarwal, R.L. 2013. Effect of fertility levels of biofertilizers on yield and economics of groundnut, Annals of Agricultural research New Series, 34(4): 353-356.

Sharma, S.K., Jain, N.K. and Upadhyay, B. 2011. Response of groundnut to balanced fertilization under sub- humid southern plain zone of Rajsthan. Legume Res. 34(4): 273-277.

Thorave, D. S. and Dhonde, M. B. 2008. Effect of integrated nutrient management on yield and nutrient uptake in summer groundnut. Journal of Maharashtra agricultural university, 33(2): 284-285.

Vaghasia, P.M. and Bhalu, V.B. 2016.Nutrient requirement for bold seeded confectionery groundnut (Arachis hypogaea $\mathrm{L}$.) under irrigated condition. International Journal of Agricultural Sciences, 12(1): 81-84.

\section{How to cite this article:}

Vora, V.D., D.S. Hirpara, P.D. Vekaria, K. Jotangiya, S.C. Kaneria, N.R. Desai and Modhavadiya, V.L. 2019. Effect of Nutrients Management Modules for Minimizing Drought Impact and Groundnut Yield Maximization in Rainfed Conditions. Int.J.Curr.Microbiol.App.Sci. 8(11): 443-449. doi: https://doi.org/10.20546/ijcmas.2019.811.055 